\title{
Body surface area as a prognostic marker in chronic heart failure patients: results from the Heart Failure Registry of the Heart Failure Association of the European Society of Cardiology
}

\author{
Barak Zafrir ${ }^{1}$, Nabeeh Salman ${ }^{2}$, María G. Crespo-Leiro ${ }^{3}$, Stefan D. Anker ${ }^{4}$, Andrew J. \\ Coats $^{5}$, Roberto Ferrari ${ }^{6}$, Gerasimos Filippatos ${ }^{7}$, Aldo P. Maggioni ${ }^{8}$, Alexandre \\ Mebazaa $^{9}$, Massimo Francesco Piepoli ${ }^{10}$, Frank Ruschitzka ${ }^{11}$, María J. Paniagua- \\ Martin $^{3}$, Javier Segovia ${ }^{12}$, Cecile Laroche ${ }^{8}$, and Offer Amir ${ }^{2}$, on behalf of the Heart \\ Failure Long-Term Registry Investigators
}

\footnotetext{
${ }^{1}$ Department of Cardiovascular Medicine, Lady Davis Carmel Medical Center, Haifa, Israel; ${ }^{2}$ Department of Cardiovascular Medicine, Poriya Medical Center, Tiberius, Israel, and Faculty of Medicine, Bar-Ilan University, Israel; ${ }^{3}$ Unidad de Insuficiencia Cardiaca Avanzada y Trasplante Cardiaco, Complexo Hospitalario Universitario A Coruna, CHUAC, La Coruna, Spain; ${ }^{4}$ Innovative Clinical Trials, Department of Cardiology \& Pneumology, University Medical Center Göttingen (UMG), Göttingen, Germany; ${ }^{5}$ Monash University, Australia, and University of Warwick, Coventry, UK; ${ }^{6}$ Department of Cardiology and LTTA Centre, University Hospital of Ferrara, and Maria Cecilia Hospital, GVM Care\&Research, E.S: Health Science Foundation, Cotignola, Italy; ${ }^{7}$ Heart Failure Unit, Department of Cardiology, Athens University Hospital Attikon, Athens, Greece; ${ }^{8}$ EURObservational Research Programme, European Society of Cardiology, Sophia-Antipolis, France; ${ }^{9}$ Hôpital Lariboisière, Université Paris Diderot, Inserm 942, Paris, France; ${ }^{10}$ Heart Failure Unit, Cardiac Department, Guglielmo da Saliceto Hospital, AUSL, Piacenza, Italy; ${ }^{11}$ Department of Cardiology, Heart Failure Clinic and Transplantation, University Heart Center Zurich, Zurich, Switzerland; and ${ }^{12}$ Advanced Heart Failure, Transplant and Pulmonary Hypertension Unit, Cardiology Department, Hospital Universitario Puerta de Hierro Majadahonda, Madrid, Spain
}

\begin{abstract}
Aims. The 'obesity paradox' is consistently observed in patients with heart failure (HF). We investigated the relationship of body surface area (BSA) to mortality and hospitalizations in patients with chronic HF.

Methods and results. Data from the outpatient cohort of the observational, prospective, Heart Failure Long-Term Registry of the Heart Failure Association of the European Society of Cardiology was analysed in order to evaluate the prognostic significance of BSA in chronic HF. A total of 9104 chronic HF patients (age $64.8 \pm 13.4$ years; $71.6 \%$ males) were enrolled. Mortality during 1-year follow-up was observed in 718 of 8875 (8.1\%) patients. A progressive, inverse relationship between all-cause mortality and BSA levels was observed; the adjusted hazard ratio (HR) for 1year mortality was 1.823 [95\% confidence interval (CI) 1.398-2.376], $P<0.001$ for the lowest quartile of BSA $<1.78$ $\mathrm{m}^{2}$, and $1.255,95 \%$ CI $1.000-1.576, P=0.05$ for the middle two quartiles $\left(1.78 \leq \mathrm{BSA} \leq 2.07 \mathrm{~m}^{2}\right)$, compared with the highest quartile (BSA >2.07 $\mathrm{m}^{2}$ ). For each increase of $0.1 \mathrm{~m}^{2}$ in BSA, an adjusted HR of 0.908 (95\% CI 0.870 $0.948), P<0.001$ for mortality was calculated. HF hospitalizations were not associated with BSA subgroup distribution. In both genders, subjects within the lowest BSA quartile (males $<1.84 \mathrm{~m}^{2}$ and females $<1.64 \mathrm{~m}^{2}$ ) had significantly higher mortality rates during follow-up (log-rank $P<0.0001)$. However, the stepwise association with mortality was more distinct in males.

Conclusions. Total and cardiovascular mortality, but not HF hospitalizations was inversely associated with BSA levels in chronic HF patients. BSA may serve as a prognostic indicator for adverse outcome in HF patients.
\end{abstract}

Keywords

Heart failure; Body surface area; Obesity; Prognosis 


\section{Introduction}

Obesity is an established risk factor for the development of cardiovascular diseases including heart failure (HF). ${ }^{1}$ However, numerous studies have demonstrated survival benefit of overweight and mildly obese HF subjects compared with leaner individuals with $\mathrm{HF}$, and the unfavourable prognostic significance of loss of body weight. ${ }^{2-11}$ This phenomenon of reverse epidemiology was termed the 'obesity paradox', and is now well documented in chronic HF.

Mechanisms explaining the obesity paradox in HF are not clearly defined, and include the effects of cardiac cachexia, catabolic state, and muscle wasting in lean HF subjects, in contrast to greater metabolic reserve and increased muscle mass and strength in overweight and obese HF individuals. ${ }^{12,13}$ It may also be that obese patients present earlier in their disease course due to greater functional impairment and are therefore treated earlier. Furthermore, it is possible that confounding factors such as disease severity, lower incidence of smoking, and younger age may account for the inverse relationship between obesity and mortality seen in HF cohorts. ${ }^{14}$, 15 Nevertheless, it is still debated whether there is an intrinsic association between obesity and mortality in HF subjects, or whether the obesity paradox is confounded by other uncontrolled factors contributing to its existence. ${ }^{16-18}$

Body mass index (BMI) is the most common anthropometric parameter used in studies assessing obesity in patients with chronic HF, due to its widespread acceptance and ease of use. Less commonly, measures of body composition such as increased waist circumference and estimates of body fat were also shown to be associated with improved outcomes in HF. ${ }^{19,20}$ Though commonly used, BMI may not be a reliable method to assess the distribution and degree of adiposity or a good way to correct weight for height. Body surface area (BSA), a method for describing body size, is commonly used as a biometric unit to adjust mass and volume and for indexing physiological parameters associated with cardiovascular disease, and may correlate more closely with prognosis in $\mathrm{HF}^{21}$ Although BSA is commonly used as a way to 'index' haemodynamic parameters, its prognostic significance in HF has not been robustly studied.

The objective of the current study was to examine the prognostic significance of BSA in predicting survival and hospitalizations in a large population of chronic HF patients.

\section{Methods}

\section{Study design}

The chronic HF cohort of the Heart Failure Long-Term Registry comprised the study population. ${ }^{22}$ This registry is a prospective, multicentre, observational study of patients presenting to 211 Cardiology centres of 21 European and Mediterranean countries. Patients were enrolled in the registry from outpatient HF clinics as well as from hospital admissions for acute, pre-existing, or new-onset HF during the enrolment period, on a 'one day per week' basis for 12 consecutive months in each participating country.

Included in the present study were all recruited outpatients with chronic HF diagnosed according to the clinical judgement of the responsible cardiologist at the participating centres. The cohort of inpatients admitted to hospitals for acute HF was not part of the present analysis. There were no specific exclusion criteria, with the exception that all patients had to be aged over 18 years. The survey was approved by each local Institutional Review Board according to the rules of each participating country. No data were collected before detailed information was provided to the patient, and a signed, informed consent was obtained. 
Baseline demographics, clinical characteristics, and co-morbidities were recorded in all patients, including drug treatment and laboratory blood tests at study entry. One-year outcome data were collected in each participating site, including overall and cardiovascular mortality, as well as HF hospitalizations during the follow-up period.

All subjects had documented BSA measurements carried out at their initial visit to the outpatient HF clinic. BSA was calculated according to the Mosteller formula [weight $(\mathrm{kg}) \times$ height $(\mathrm{cm}) / 3600]^{1 / 2}{ }^{23}$ Mosteller's formula is recommended as an accurate measure to estimate BSA, and is commonly used due to its simplicity and applicability in both clinical and laboratory medicine. ${ }^{24}$

\section{Statistical analysis}

Univariate analysis was applied to both continuous and categorical variables. Continuous variables were reported as mean \pm SD or as median and interquartile range (IQR). Among-group comparisons were made using a non-parametric test (Kruskal-Wallis test). Categorical variables were reported as percentages. Intergroup comparisons were made using a $\chi^{2}$ test or a Fisher's exact test if any expected cell count was less than five. In order to assess the prognostic value of BSA, the patients were categorized into three groups based on quartiles of BSA [<Q1 $\left(1.78 \mathrm{~m}^{2}\right)$; Q1-Q3 $\left(1.78-2.07 \mathrm{~m}^{2}\right)$; >Q3 $\left(2.07 \mathrm{~m}^{2}\right)$ ]. Additional analysis was performed for BSA as a continuous variable.

Multivariable analysis was performed using the Cox proportional hazards analysis. All variables significant in a univariate analysis were inserted in the model. A stepwise regression model was performed, where BSA was the fixed variable. Hazard ratios (HRs) for overall 1-year mortality were calculated for the subgroups of BSA and additional significant covariables, with $95 \%$ confidence intervals (CIs). Adjustment for age and gender was also performed in a separate model in order to assess the effect of age and gender on the association between BSA and mortality.

Survival curves were plotted by the Kaplan-Meier method using the log-rank test for assessing the significance of the differences in survival between BSA subgroups. As BSA values are commonly lower in females than in males, additional plots were made according to the specific quartiles of each gender.

The results were considered statistically significant when the $P$-value was $<0.05$. Analyses were performed with SAS statistical software version 9.4 (SAS Institute, Inc., Cary, NC, USA).

\section{Results}

Included in the study were 9104 participants of the outpatient cohort of the ESC Heart Failure LongTerm Registry. The baseline characteristics of the patients included in the study are presented in Table 1. Mean age of the study population was $64.8 \pm 13.4$ years, and there was predominance of men $(71.6 \%)$. Only $25.7 \%$ were in NYHA functional class III-IV. An LVEF of $\leq 45 \%$ was documented in $77.0 \%$ of the patients. Ischaemic heart disease as a primary aetiology was present in $42.8 \%$ and diabetes mellitus in $31.3 \%$. 
Table 1. Baseline characteristics of patients according to body surface area $\left(\mathrm{m}^{2}\right)$

\begin{tabular}{|c|c|c|c|c|c|}
\hline & All $(n=9104)$ & $<1.78(n=2226)$ & $1.78-2.07(n=4652)$ & $>2.07(n=2226)$ & $P$-value \\
\hline Age (years) & $64.8 \pm 13.4$ & $67.6 \pm 15.1$ & $65.4 \pm 12.8$ & $60.6 \pm 11.6$ & $<0.001$ \\
\hline Female gender & $2584 / 9104(28.4 \%)$ & $1310 / 2226(58.9 \%)$ & $1074 / 4652(23.1 \%)$ & $200 / 2226(9.0 \%)$ & $<0.001$ \\
\hline $\operatorname{BMI}\left(\mathrm{kg} / \mathrm{m}^{2}\right)$ & $28.1 \pm 5.1$ & $23.8 \pm 3.3$ & $27.8 \pm 3.6$ & $33.0 \pm 5.1$ & $<0.001$ \\
\hline $\mathrm{SBP}(\mathrm{mmHg})$ & $124.4 \pm 21.0$ & $120.8 \pm 21.0$ & $124.4 \pm 20.7$ & $128.1 \pm 20.8$ & $<0.001$ \\
\hline HR (b.p.m.) & $73.2 \pm 15.7$ & $72.6 \pm 15.3$ & $72.6 \pm 15.4$ & $74.9 \pm 16.5$ & $<0.001$ \\
\hline $\mathrm{EF}(\%)$ & $37.1 \pm 13.6$ & $38.2 \pm 15.1$ & $37.0 \pm 13.4$ & $36.1 \pm 12.5$ & 0.008 \\
\hline $\mathrm{EF}(\%)$ median (IQR) & $35(27-45)$ & $35(27-49)$ & $35(28-45)$ & $35(27-45)$ & \\
\hline NYHA III-IV & $2343 / 9102(25.7 \%)$ & $599 / 2226(26.9 \%)$ & $1142 / 4651(24.6 \%)$ & $602 / 2225(27.1 \%)$ & 0.030 \\
\hline Sound 3 & $547 / 9060(6.0 \%)$ & $126 / 2216(5.7 \%)$ & $281 / 4633(6.1 \%)$ & $140 / 2211(6.3 \%)$ & 0.661 \\
\hline Mitral regurgitation & $2415 / 9079(26.6 \%)$ & $619 / 2220(27.9 \%)$ & $1233 / 4640(26.6 \%)$ & $563 / 2219(25.4 \%)$ & 0.166 \\
\hline Aortic stenosis & $370 / 9077(4.1 \%)$ & $123 / 2219(5.5 \%)$ & $181 / 4640(3.9 \%)$ & $66 / 2218(3.0 \%)$ & $<0.001$ \\
\hline HF history with previous hospitalization & $3767 / 9043(41.7 \%)$ & $954 / 2219(43.0 \%)$ & $1904 / 4611(41.3 \%)$ & $909 / 2213(41.1 \%)$ & 0.335 \\
\hline Ischaemic heart disease & $3900 / 9104(42.8 \%)$ & $803 / 2226(36.1 \%)$ & $2139 / 4652(46.0 \%)$ & $958 / 2226(43.0 \%)$ & $<0.001$ \\
\hline Atrial fibrillation & $3370 / 9104(37.0 \%)$ & $780 / 2226(35.0 \%)$ & $1709 / 4652(36.7 \%)$ & $881 / 2226(39.6 \%)$ & 0.006 \\
\hline Diabetes mellitus & $2853 / 9104(31.3 \%)$ & $511 / 2226(23.0 \%)$ & $1486 / 4652(31.9 \%)$ & $856 / 2226(38.5 \%)$ & $<0.001$ \\
\hline PAD & $1100 / 9081(12.1 \%)$ & $273 / 2219(12.3 \%)$ & $583 / 4640(12.6 \%)$ & $244 / 2222(11.0 \%)$ & 0.162 \\
\hline Hypertension & $5357 / 9098(58.9 \%)$ & $1138 / 2223(51.2 \%)$ & $2756 / 4649(59.3 \%)$ & $1463 / 2226(65.7 \%)$ & $<0.001$ \\
\hline COPD & $1272 / 9089(14.0 \%)$ & $295 / 2222(13.3 \%)$ & $632 / 4643(13.6 \%)$ & $345 / 2224(15.5 \%)$ & 0.056 \\
\hline Prior stroke/TIA & $844 / 9098(9.3 \%)$ & $193 / 2224(8.7 \%)$ & $479 / 4648(10.3 \%)$ & $172 / 2226(7.7 \%)$ & 0.001 \\
\hline Renal dysfunction & $1746 / 9095(19.2 \%)$ & $453 / 2225(20.4 \%)$ & $905 / 4645(19.5 \%)$ & $388 / 2225(17.4 \%)$ & 0.036 \\
\hline Hepatic dysfunction & $320 / 9090(3.5 \%)$ & $70 / 2222(3.2 \%)$ & $167 / 4643(3.6 \%)$ & $83 / 2225(3.7 \%)$ & 0.531 \\
\hline Depression & $666 / 9075(7.3 \%)$ & $202 / 2215(9.1 \%)$ & $348 / 4637(7.5 \%)$ & $116 / 2223(5.2 \%)$ & $<0.001$ \\
\hline CRT implantation & $1187 / 9020(13.2 \%)$ & $285 / 2214(12.9 \%)$ & $611 / 4606(13.3 \%)$ & $291 / 2200(13.2 \%)$ & 0.899 \\
\hline ICD implantation & $2204 / 9028(24.4 \%)$ & $454 / 2216(20.5 \%)$ & $1165 / 4610(25.3 \%)$ & $585 / 2202(26.6 \%)$ & $<0.001$ \\
\hline
\end{tabular}

BMI, body mass index; BSA, body surface area; HF, heart failure; HR, heart rate; ICD, implantable cardioverter defibrillator; IQR, interquartile range; PAD, peripheral artery disease; SBP, systolic blood pressure; TIA, transient ischaemic attack.

Study patients were divided according to quartiles of BSA [ $<1.78 \mathrm{~m}^{2}(\mathrm{Q} 1) ;\left(1.78-2.07 \mathrm{~m}^{2}\right)(\mathrm{Q} 1-\mathrm{Q} 3)$; $\left.>2.07 \mathrm{~m}^{2}(\mathrm{Q} 3)\right]$. Higher BSA subgroups were significantly associated with younger age and predominance of male gender. In addition, higher BSA was associated with greater prevalence of comorbidities, including obesity, hypertension, diabetes mellitus, and AF. The rate of depression was inversely related to BSA.

Drug treatment and laboratory blood tests during outpatient visits according to BSA subgroups are presented in Table 2. Almost 90\% of patients were treated with ACE inhibitors or ARBs as well as betablockers; $83.1 \%$ with oral diuretics; and 59.5\% with mineralocorticoid receptor antagonists (MRAs). The usage of these therapies was higher across BSA subgroups. Creatinine, uric acid, white blood cells, and high-sensitivity C-reactive protein levels were significantly higher with the increase in BSA levels (Table 2). 
Table 2. Drug treatment and laboratory blood tests during outpatient visits according to body surface $\operatorname{area}\left(\mathrm{m}^{2}\right)$

\begin{tabular}{|c|c|c|c|c|c|}
\hline & All $(n=9104)$ & $<1.78(n=2226)$ & $1.78-2.07(n=4652)$ & $>2.07(n=2226)$ & $P$-value \\
\hline \multicolumn{6}{|l|}{ Drug treatment } \\
\hline ACE inibitors/ARBs & $8061 / 9093(88.7 \%)$ & $1836 / 2224(82.6 \%)$ & $4141 / 4644(89.2 \%)$ & $2084 / 2225(93.7 \%)$ & $<0.001$ \\
\hline Beta-blockers & $8057 / 9101(88.5 \%)$ & $1885 / 2225(84.7 \%)$ & $4125 / 4650(88.7 \%)$ & $2047 / 2226(92.0 \%)$ & $<0.001$ \\
\hline MRAs & $5414 / 9101(59.5 \%)$ & $1270 / 2225(57.1 \%)$ & $2766 / 4650(59.5 \%)$ & $1378 / 2226(61.9 \%)$ & 0.005 \\
\hline Diuretics, oral & $7559 / 9100(83.1 \%)$ & $1823 / 2224(82.0 \%)$ & $3855 / 4650(82.9 \%)$ & $1881 / 2226(84.5 \%)$ & 0.072 \\
\hline Digitalis & $2106 / 9098(23.2 \%)$ & $511 / 2225(23.0 \%)$ & $1061 / 4647(22.8 \%)$ & $534 / 2226(24.0 \%)$ & 0.552 \\
\hline Statins & $5519 / 9100(60.7 \%)$ & $1188 / 2225(53.4 \%)$ & $2931 / 4649(63.1 \%)$ & $1400 / 2226(62.9 \%)$ & $<0.001$ \\
\hline Antiplatelets & $4480 / 9100(49.2 \%)$ & $1003 / 2225(45.1 \%)$ & $2403 / 4649(51.7 \%)$ & $1074 / 2226(48.3 \%)$ & $<0.001$ \\
\hline Oral anticoagulant & $3844 / 9099(42.3 \%)$ & $892 / 2225(40.1 \%)$ & $1951 / 4648(42.0 \%)$ & $1001 / 2226(45.0 \%)$ & 0.004 \\
\hline Amiodarone & 1276/9099 (14.0\%) & $275 / 2225(12.4 \%)$ & $644 / 4648(13.9 \%)$ & $357 / 2226(16.0 \%)$ & 0.002 \\
\hline Ivabradine & $763 / 9099(8.4 \%)$ & $203 / 2225(9.1 \%)$ & $370 / 4648(8.0 \%)$ & $190 / 2226(8.5 \%)$ & 0.255 \\
\hline Nitrates & $1763 / 9098(19.4 \%)$ & $400 / 2224(18.0 \%)$ & $954 / 4648(20.5 \%)$ & $409 / 2226(18.4 \%)$ & 0.017 \\
\hline Calcium channel blockers & 1039/9098 (11.4\%) & $191 / 2225(8.6 \%)$ & $549 / 4648(11.8 \%)$ & $299 / 2225(13.4 \%)$ & $<0.001$ \\
\hline \multicolumn{6}{|l|}{ Laboratory blood tests } \\
\hline WBC (cells/ $\mu \mathrm{L})$ & $7613.6 \pm 6098.4$ & $7581.6 \pm 10360.2$ & $7539.7 \pm 4312.0$ & $7799.5 \pm 2152.5$ & $<0.001$ \\
\hline Creatinine (mg/dL) & $1.29 \pm 2.30$ & $1.23 \pm 0.92$ & $1.28 \pm 1.91$ & $1.36 \pm 3.63$ & $<0.001$ \\
\hline Uric acid (mg/dL) & $6.86 \pm 2.79$ & $6.46 \pm 3.04$ & $6.90 \pm 2.90$ & $7.17 \pm 2.19$ & $<0.001$ \\
\hline Total cholesterol (mg/dL) & $167.94 \pm 45.1$ & $172.12 \pm 45.82$ & $166.40 \pm 44.23$ & $167.10 \pm 45.93$ & $<0.001$ \\
\hline Sodium (mmol/L) & $139.37 \pm 3.76$ & $139.17 \pm 3.91$ & $139.44 \pm 3.72$ & $139.45 \pm 3.66$ & 0.131 \\
\hline Potassium (mmol/L) & $4.46 \pm 0.53$ & $4.47 \pm 0.55$ & $4.47 \pm 0.52$ & $4.42 \pm 0.52$ & 0.004 \\
\hline hsCRP (mg/L) & $7.14 \pm 12.74$ & $6.28 \pm 11.12$ & $6.66 \pm 12.20$ & $8.84 \pm 14.87$ & $<0.001$ \\
\hline Bilirubin (mg/dL) & $0.87 \pm 0.84$ & $0.85 \pm 0.64$ & $0.86 \pm 1.01$ & $0.90 \pm 0.59$ & 0.027 \\
\hline
\end{tabular}

BSA, body surface area; hsCRP, high-sensitivity C-reactive protein; MRA, mineralocorticoid receptor antagonist; WBC, white blood cells.

\section{Follow-up outcomes}

Data regarding mortality during 1-year follow-up were available in 8875 patients $(97.5 \%$ of the study cohort). Out of this population, $718(8.1 \%)$ patients have died. An inverse relationship between all-cause mortality and BSA subgroups was observed: highest in the low BSA quartile (11.4\%), lower mortality in the Q1-Q3 quartiles (7.6\%), and lowest in the uppermost BSA quartile (5.7\%), $P<0.001$ (Table 3). Cardiovascular death was determined in 371 patients $(4.2 \%$ of the study cohort) and was inversely associated with BSA subgroup distribution $(P<0.001)$. Recurrent HF hospitalizations during 1 -year follow-up were documented in 1029 of 8316 patients (12.4\%), and were not significantly different between BSA subgroups $(P=0.392)$. 
Table 3. One-year outcomes according to body surface area subtypes $\left(\mathrm{m}^{2}\right)$

\begin{tabular}{llllll}
\hline & All $(n=9104)$ & $<1.78(n=2226)$ & $1.78-2.07(n=4652)$ & $>2.07(n=2226)$ & $P$-value \\
\hline & & & & & \\
All causes of death & $718 / 8875(8.1 \%)$ & $247 / 2165(11.4 \%)$ & $347 / 4541(7.6 \%)$ & $124 / 2169(5.7 \%)$ & $<0.001$ \\
CV death & $371 / 8875(4.2 \%)$ & $131 / 2165(6.1 \%)$ & $178 / 4541(3.9 \%)$ & $62 / 2169(2.8 \%)$ & $<0.001$ \\
Non-CV death & $162 / 8875(1.8 \%)$ & $59 / 2165(2.7 \%)$ & $75 / 4541(1.6 \%)$ & $28 / 2169(1.3 \%)$ & $<0.001$ \\
Unknown & $185 / 8875(2.1 \%)$ & $57 / 2165(2.6 \%)$ & $94 / 4541(2.1 \%)$ & $34 / 2169(1.6 \%)$ & 0.049 \\
HF hospitalization & $1029 / 8316(12.4 \%)$ & $263 / 2049(12.8 \%)$ & $506 / 4255(11.9 \%)$ & $260 / 2012(12.9 \%)$ & 0.392 \\
& & & & & \\
\hline
\end{tabular}

BSA, body surface area; CV, cardiovascular; HF, heart failure.

\section{Predictors of all-cause mortality}

Multivariable analysis was performed by Cox regression analysis to identify independent predictors for all causes of 1-year mortality. Multiple variables including baseline characteristics, co-morbidities, and drug therapies were significantly and independently associated with mortality, as shown in Table 4. Other than severely reduced functional class (NYHA III-IV) (HR 2.152, 95\% CI 1.822-2.541), the lowest BSA quartile (BSA $<1.78 \mathrm{~m}^{2}$ ) was the strongest predictor of 1-year mortality compared with the highest quartile $\left(\mathrm{BSA}>2.07 \mathrm{~m}^{2}\right.$ ) in the multivariate model (HR 1.823, 95\% CI 1.398-2.376).

Table 4. Multivariable predictors for all causes of 1-year mortality

\begin{tabular}{lll}
\hline Variable & \multicolumn{2}{l}{ Multivariable analysis } \\
\cline { 2 - 3 } & HR $(95 \%$ CI $)$ & $P$-value \\
\hline & & \\
${\text { BSA }<1^{\mathrm{a}}}$ & $1.823(1.398-2.376)$ & $<0.0001$ \\
BSA Q1-Q3 $^{\mathrm{a}}$ & $1.255(1.000-1.576)$ & 0.0503 \\
Female gender $^{\mathrm{b}}$ & $0.657(0.534-0.808)$ & $<0.0001$ \\
Age (years) & $1.026(1.018-1.034)$ & $<0.0001$ \\
Systolic BP (mmHg) & $0.985(0.981-0.989)$ & $<0.0001$ \\
LVEF <45\% & $1.387(1.108-1.736)$ & 0.0042 \\
NYHA III-IV & $2.152(1.822-2.541)$ & $<0.0001$ \\
S3 gallop & $1.374(1.042-1.813)$ & 0.0245 \\
Mitral regurgitation & $1.223(1.033-1.448)$ & 0.0193 \\
Aortic stenosis & $1.531(1.140-2.055)$ & 0.0047 \\
Atrial fibrillation & $1.332(1.129-1.572)$ & 0.0007 \\
Diabetes mellitus & $1.403(1.188-1.657)$ & $<0.0001$ \\
Peripheral vascular disease & $1.463(1.197-1.789)$ & 0.0002 \\
Chronic kidney dysfunction & $1.628(1.366-1.940)$ & $<0.0001$ \\
Hepatic dysfunction & $1.342(0.983-1.831)$ & 0.0642 \\
Depression & $1.411(1.104-1.804)$ & 0.0059 \\
ACE inhibitor and/or ARB & $0.756(0.615-0.929)$ & 0.0079 \\
Beta-blockers & $0.653(0.527-0.810)$ & 0.0001 \\
& & \\
\hline
\end{tabular}

BP, blood pressure; BSA, body surface area; CI, confidence interval; HR, hazard ratio; Q, quartile.

${ }^{a}$ Reference value BSA > Q3

${ }^{b}$ Reference value male.

${ }^{c}$ Reference value $\mathrm{LVEF} \geq 45 \%$ 
Table 5 shows the HR for 1-year mortality according to BSA levels. In addition to the unadjusted model, data are presented after full adjustment for all significant covariates, and separately after adjustment for age and gender, the most significant parameters influencing BSA. BSA displayed a significant, stepwise, inverse relationship with all-cause mortality in all models, including after comprehensive adjustment for confounders. The HR for 1-year mortality was 1.823 (95\% CI 1.3982.376) for the lowest quartile of BSA $<1.78 \mathrm{~m}^{2}$ and 1.255 (95\% CI 1.000-1.576) for the Q1-Q3 quartiles $\left(1.78<\mathrm{BSA}<2.07 \mathrm{~m}^{2}\right)$, compared with the highest quartile $\left(\mathrm{BSA}>2.07 \mathrm{~m}^{2}\right)$. Moreover, entering BSA as a continuous variable showed similar results, with an adjusted HR of 0.908 (95\% CI $0.870-0.948$ ) for each increase of $0.1 \mathrm{~m}^{2}$ in BSA levels (Table 5).

Table 5. Hazard ratios for 1-year mortality according to body surface area

\begin{tabular}{llll}
\hline Comparison & Unadjusted HR (95\% CI) & $\begin{array}{l}\text { HR adjusted for age and gender }(95 \% \\
\text { CI })\end{array}$ & HR adjusted for all ${ }^{\mathrm{a}}(95 \%$ CI $)$ \\
\hline & & & $1.452(1.197-1.760), P<$ \\
BSA < Q1 vs. Q1-Q3 & $1.529(1.299-1.800), P<$ & $1.710(1.438-2.033), P<0.001$ & 0.001 \\
& 0.001 & & $1.823(1.398-2.376), P<$ \\
BSA < Q1 vs. >Q3 & $2.073(1.670-2.572), P<$ & $2.156(1.709-2.721), P<0.001$ & 0.001 \\
& 0.001 & & $1.255(1.000-1.576), P=$ \\
BSA Q1-Q3 vs. >Q3 & $1.355(1.104-1.664), P=$ & $1.261(1.024-1.553), P=0.029$ & 0.050 \\
& 0.004 & & $0.908(0.870-0.948), P<$ \\
BSA continuous (unit $=$ & $0.888(0.859-0.918), P<$ & $0.871(0.838-0.905), P<0.001$ & 0.001 \\
$0.1)$ & 0.001 & &
\end{tabular}

Comparison between BSA quartiles or as a continuous variable, for each increase of $0.1 \mathrm{~m}^{2}$. BSA, body surface area; CI, confidence interval; HR, hazard ratio; Q, quartile.

${ }^{a}$ See Table 4.

The lowest BSA quartile was significantly associated with 1-year mortality in both patients with preserved $(\geq 45 \%)$ and reduced $(<45 \%)$ LVEF (adjusted HR 2.048, 95\% CI 1.045-4.013, $P=0.03$, and $1.804,95 \%$ CI 1.351-2.408, $P<0.001$ compared with the highest BSA quartile, respectively).

Kaplan-Meier survival curves for all causes of death, stratified by BSA subgroups, are presented in Figure 1, showing the continuation of the graded inverse relationship between BSA subgroups and mortality also beyond the first year of follow-up (log-rank $P<0.0001$ ). Because BSA is inherently influenced by gender, we additionally performed separate survival analysis according to BSA quartiles of each gender (Figure 2). In both genders, subjects with the lowest BSA quartile (males $<1.84 \mathrm{~m}^{2}$ and females $<1.64 \mathrm{~m}^{2}$ ) had significantly higher mortality rates (log-rank $P<0.0001$ for both genders). However, the stepwise association with mortality was more distinct in males. 


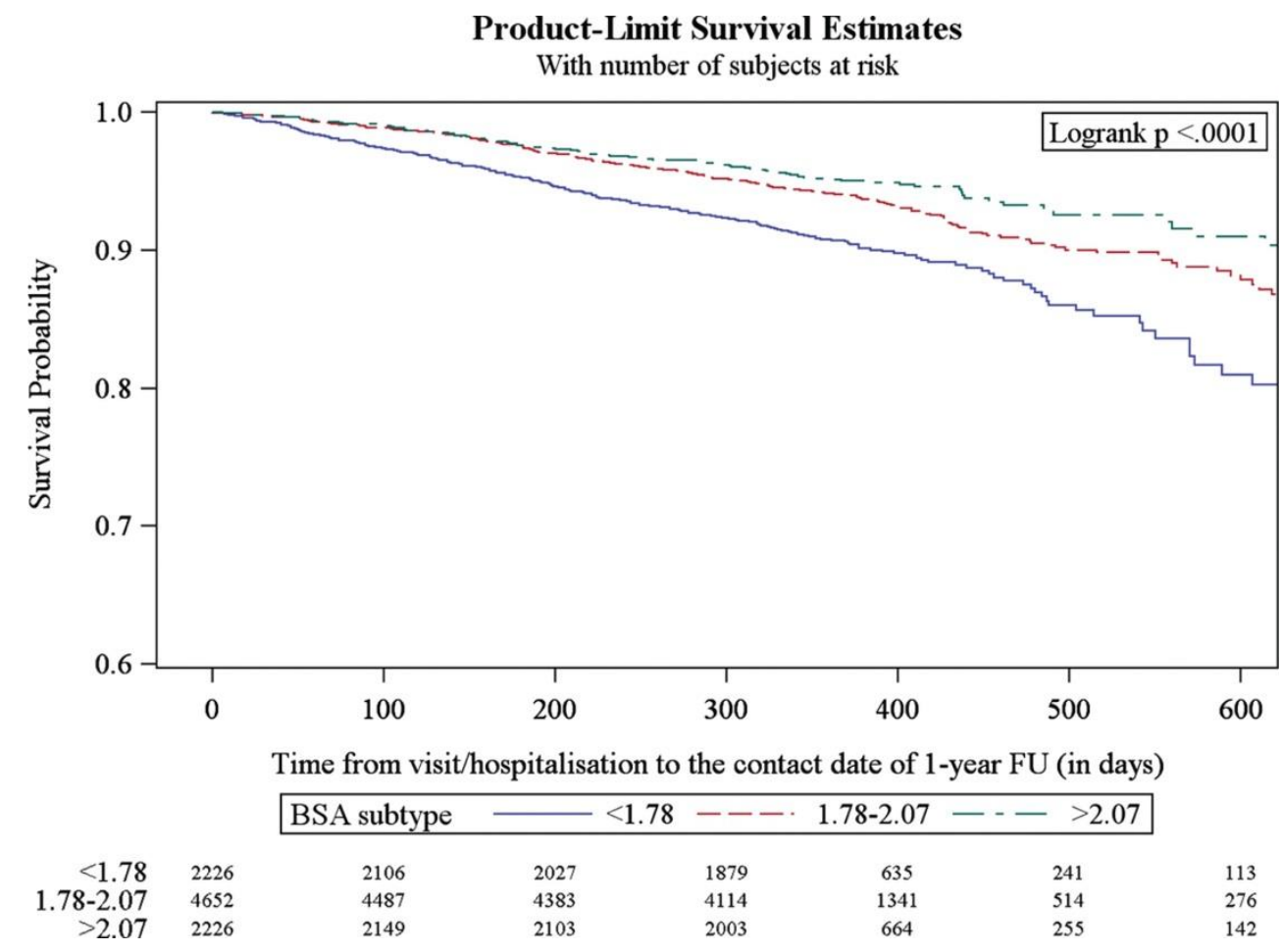

Figure 1. Kaplan-Meier curves for all causes of death by body surface area (BSA) subtypes. FU, follow-up. 
A

Product-Limit Survival Estimates

With number of subjects at risk

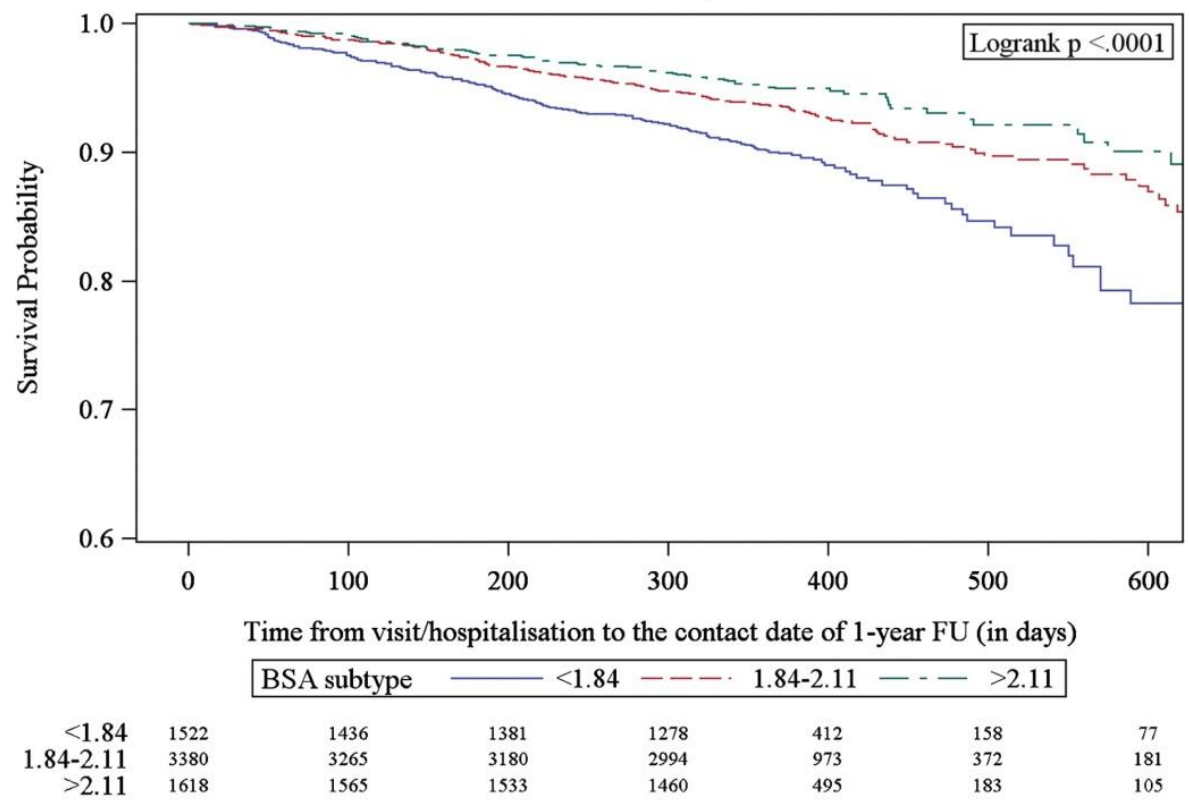

B

Product-Limit Survival Estimates

With number of subjects at risk

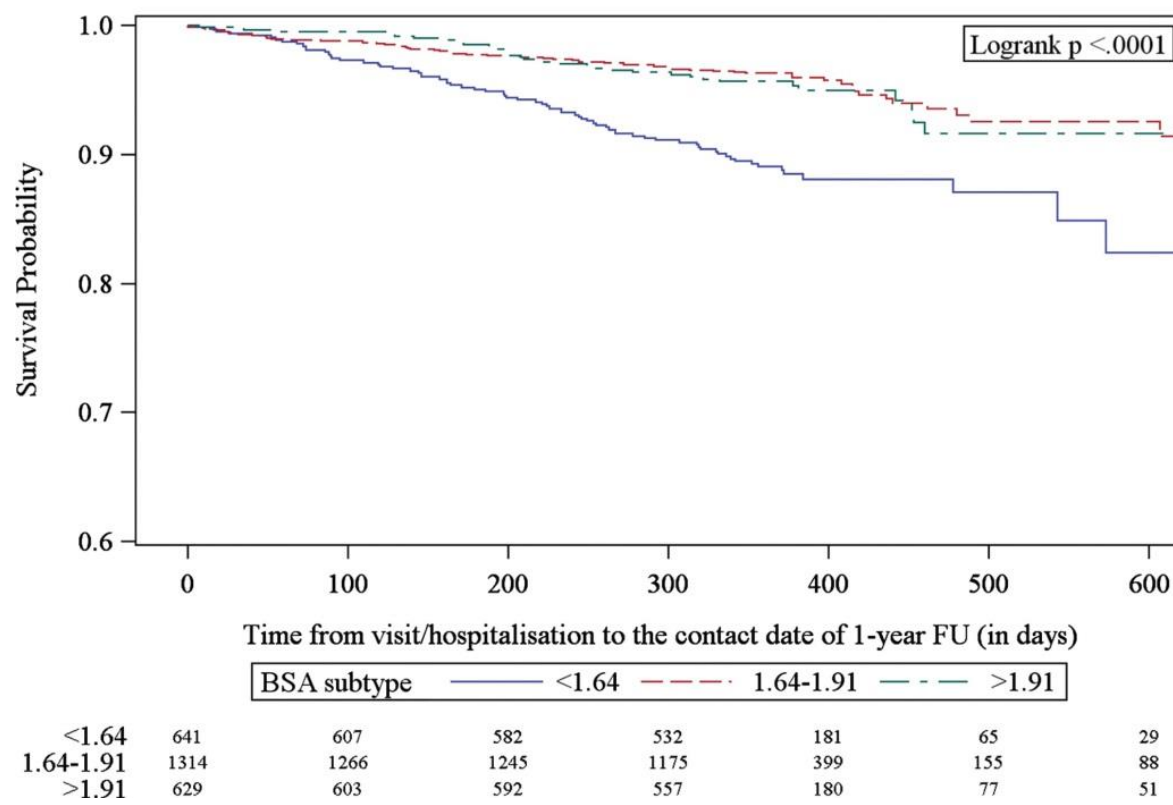

Figure 2. Kaplan-Meier curves for all causes of death by body surface area (BSA) subtypes, separately for $(A)$ males and $(B)$ females. FU, follow-up. 


\section{Discussion}

The results of the present study indicate that BSA, a common measure of body size used for indexing physiological parameters, is inversely and progressively associated with all-cause and cardiuovascular mortality, but not HF hospitalizations, in a large cohort of chronic HF patients. This relationship, coinciding with the 'obesity paradox', was noted even after significant adjustment for confounders, including age and gender.

The phenomenon of the obesity paradox was repeatedly demonstrated in studies analysing cohorts of both acute and chronic HF patients. ${ }^{2-8,}{ }^{25}$ This was documented even though obesity is a well-established risk factor for HF. ${ }^{1}$ The main mechanism proposed for the obesity paradox in HF is the greater metabolic reserve existing in obese $\mathrm{HF}$ patients, in contrast to the catabolic and inflammatory changes leading to cardiac cachexia. ${ }^{26}$ However, other contributing factors were suggested, including lower sympathetic activation and earlier presentation of symptoms in the obese HF patients, and confounding factors such as age and gender, which may bias the results. ${ }^{14-18,27}$

The majority of studies analysing adiposity in HF identified obesity by measuring BMI. However, the accuracy and reliability of this method in defining obesity and correcting weight for height was questioned. ${ }^{13,20}$ BSA correlates more closely to physiological parameters than body weight. Different formulae that estimate whole BSA were developed over the years. ${ }^{24,28}$ The DuBois brothers were the first researchers (in 1915) to develop an equation incorporating both mass and height, based on data from nine cadavers. $^{29}$ Years later, Mosteller suggested a simplified approximation to this formula in a letter published in 1987 in the New England Journal of Medicine. ${ }^{23}$ This simplified equation $[\mathrm{BSA}=($ weight $(\mathrm{kg}) \times$ height $(\mathrm{cm}) / 3600)^{1 / 2}$ ] has been widely adopted over the years due to its ease of calculation. ${ }^{28}$ Verbraecken and colleagues found a close agreement between Mosteller's equation and BSA values obtained with traditional complex methods, recommending that this formula deserves to be used as the first choice for BSA calculation in clinical research and practice. ${ }^{24}$ Importantly, they demonstrated the accuracy and applicability of the Mosteller equation not only in normal weight, but also in overweight and obese adults.

Although BSA is commonly used in medicine as a biometric unit to adjust size, mass, and volume, its clinical significance as an outcome predictor in cardiovascular diseases was scantily investigated. A small BSA was found to be an independent negative outcome predictor after coronary artery bypass surgery. ${ }^{30}$ An additional study found that adult candidates for heart transplantation with lower BSA, including most female patients, had worse prognosis. ${ }^{31}$ Moreover, specifically in chronic HF, Futter and colleagues found in a cohort of 2271 patients that BSA was a stronger predictor of mortality than other measures of body habitus including BMI, concluding that the greater the overall bulk of the body the better the survival. ${ }^{20}$ The current study results are in concordance with these observations, demonstrating an inverse relationship between BSA and mortality in chronic HF patients, establishing low BSA as one of the strongest independent predictors of 1-year mortality. The inverse relationship with mortality was stepwise, with a borderline prognostic significance of the middle vs. high BSA subgroup in the multivariate analysis.

The lack of association between BSA and HF hospitalization rates observed in the current study was similarly shown in a recent meta-analysis investigating the relationship of BMI and outcomes in patients with chronic $\mathrm{HF}^{8}$ In both studies, a U-shaped association with rehospitalizations was demonstrated, which was distinct from the inverse relationship which was seen with mortality.

In contrast to BMI, there are consistently and significantly higher BSA values in males than in females, both in normal weight and in overweight and obese subjects. The commonly accepted 50th percentiles for BSA are $1.94 \mathrm{~m}^{2}$ for adult men and $1.69 \mathrm{~m}^{2}$ for adult women. ${ }^{24}$ As expected, this observation was also noted in the present study, in which the gender distribution varied significantly across BSA quartiles. Therefore, we have adjusted the HRs of mortality for age and gender in a separate model, and analysed survival curves according to the BSA quartiles of each gender individually. The obesity paradox was demonstrated in both genders; however, there was a stronger inverse association 
between BSA and mortality in males compared with females. This finding could be partly due to the significantly higher mortality rates observed in males than in females in our HF cohort.

\section{Limitations}

The current study is based on an observational multicentre registry of HF patients. Some important limitations of this registry are acknowledged elsewhere. ${ }^{22}$ Additional co-morbidities and cardiovascular risk factors influencing HF progression and outcomes may not have been evaluated in the ESC HF registry and therefore may account for residual confounding effects which were not adjusted for in the present study. Moreover, we have not used statistical methods such as propensity score analysis for matching imbalances in baseline characteristics and disease severity between BSA subgroups. ç

Body surface ares was estimated based on a commonly used formula and not on actual BSA measurements using methods such as three-dimensional whole-body scanning. In addition, several studies have pointed out that BSA calculation is less accurate in severely obese subjects, which may have influenced the results. Moreover, we have not compared the predictive ability of BSA with BMI, the more commonly investigated parameter in studies analysing the obesity paradox in HF, nor have we evaluated whether BSA is linked to differences in body fat distribution. These important questions should be addressed in future studies.

\section{Conclusions}

Body surface area is a strong independent predictor of mortality in chronic HF subjects. Similar to other measures of body habitus, the obesity paradox is observed in HF using Mosteller's formula for BSA estimation. Since BSA is routinely calculated for indexing physiological parameters in the cardiovascular field, it may serve as an important and practicable prognostic indicator for adverse outcomes in chronic HF patients.

\section{Acknowledgements}

The authors thank the following organizers of the Heart Failure Long-Term Registry. Executive Committee: M.G. Crespo-Leiro, S.D. Anker, A.J. Coats, R. Ferrari, G. Filippatos, A.P. Maggioni, A. Mebazaa, and M.F. Piepoli; Steering Committee (National Co-ordinators): O. Amir, O. Chioncel, U. Dahlström, J.F. Delgado Jimenez, J. Drozdz, A. Erglis, E. Fazlibegovic, C. Fonseca, F. Fruhwald, P. Gatzov, E. Goncalvesova, M. Hassanein, J. Hradec, A. Kavoliuniene, M. Lainscak, D. Logeart, B. Merkely, M. Metra, M. Otljanska, P.M. Seferovic, E. Srbinovska Kostovska, A. Temizhan, and D. Tousoulis. EORP Team: M. Andarala, T. Ferreira, E. Fiorucci, E. Folkesson, M. Glémot, G. Gracia, M. Konte, C. Laroche, PA. McNeill, V. Missiamenou, C. Pommier, and C. Taylor,

\section{Funding}

Since the start of the EURObservational Research Programme, the following companies have supported the programme: Abbott Vascular International (2011-2014), Amgen (2012-2015), AstraZeneca (2014-2017), Bayer Pharma AG (2013-2015), Boehringer Ingelheim (2013-2016), Boston Scientific (2010-2012), the Bristol Myers Squibb and Pfizer Alliance (2014-2016), the Daiichi Sankyo Europe GmbH and Eli Lilly and Company Alliance (2014-2017), Gedeon Richter PLC (2014-2017), Menarini Int. Op. (2010-2012), MSD-Merck \& Co. (2011-2014), Novartis Pharma AG (2014-2017), ResMed (2014-2016), Sanofi (2010-2011), and Servier (2012-2015). 
Conflict of interest: F.R. reports grants and personal fees from SJM, and personal fees from Servier, Zoll, AstraZeneca, and HeartWare, outside the submitted work; A.M. reports personal fees from Novartis, Orion, Roche, Servier, Cardiorentis, and Zs Pharma, grants and personal fees from Adrenomed, and grants from MyCartis and Critical diagnostics, outside the submitted work; A.P.M. reports personal fees from Novartis, Cardiorentis, and Bayer, outside the submitted work; S.D.A. reports personal fees from Novartis and Servier, grants and personal fees from Vifor Int. and Bayer, and grants from Abbott Vascular, during the conduct of the study; M.G.C.-L. reports grants and personal fees from Novartis, and other fees from Abbott and Servier, during the conduct of the study; R.F. reports grants and personal fees from Servier, Boehringer Ingelheim, and Novartis, personal fees from Merck Serono and Amgen, and grants from Irbtech, outside the submitted work. All other authors have no conflict to declare.

\section{Appendix}

AUSTRIA Braunau: J. Auer; Graz: K. Ablasser, F. Fruhwald, T. Dolze, K. Brandner; Innsbruck: S. Gstrein, G. Poelzl; Sankt Poelten: D. Moertl; Vienna: S. Reiter, A. Podczeck-Schweighofer; BOSNIA HERZEGOVINA Mostar: A. Muslibegovic, M. Vasilj, E. Fazlibegovic, M. Cesko, D. Zelenika, B. Palic, D. Pravdic, D. Cuk; BULGARIA Sofia: K. Vitlianova, T. Katova, T. Velikov, T. Kurteva, P. Gatzov, Vidin: D. Kamenova; Varna: M. Antova, V. Sirakova; CZECH REPUBLIC Brno: J. Krejci, M. Mikolaskova, J. Spinar; Prague: J. Krupicka, F. Malek, M. Hegarova; Olomouc: M. Lazarova; Znojmo: Z. Monhart; EGYPT Alexandria: M. Hassanein, M. Sobhy, F. El Messiry, A.H. El Shazly, Y. Elrakshy; Assiut: A. Youssef; Benha: A.A. Moneim; Cairo: M. Noamany, A. Reda, T.K. Abdel Dayem, N. Farag, S. Ibrahim Halawa, M. Abdel Hamid, K. Said, A. Saleh; Damanhour, El Beheira: H. Ebeid; Giza Cairo: R. Hanna, R. Aziz, O. Louis, M.A. Enen, B.S. Ibrahim; Ismailya: G. Nasr; Port Said: A. Elbahry; Tanta: H. Sobhy, M. Ashmawy; Zagazig: M. Gouda, W. Aboleineen; FRANCE Besançon: Y. Bernard, P. Luporsi, N. Meneveau, M. Pillot, M. Morel, M-F. Seronde, F. Schiele, F. Briand; Bron - Lyon: F. Delahaye; Créteil: T. Damy; Dijon: J-C. Eicher; Lille: P. de Groote, M. Fertin, N. Lamblin; Paris: R. Isnard, C. Lefol, S. Thevenin, A. Hagege, G. Jondeau, D. Logeart; Poitiers: V. Le Marcis, J-F. Ly, D. Coisne, B. Lequeux; Rennes: V. Le Moal, S. Mascle, P. Lotton, N. Behar, E. Donal, C. Thebault, C. Ridard, A. Reynaud, A. Basquin; Rouen: F. Bauer; Senlis: R. Codjia; Toulouse: M. Galinier; GREECE Athens: P. Tourikis, M. Stavroula, D. Tousoulis, C. Stefanadis, C. Chrysohoou, I. Kotrogiannis, V. Matzaraki, T. Dimitroula, A. Karavidas, G. Tsitsinakis, C. Kapelios, J. Nanas, H. Kampouri, E. Nana, E. Kaldara, A. Eugenidou; Heraklion, Crete: P. Vardas, I. Saloustros, A. Patrianakos; Volos: T. Tsaknakis, S. Evangelou, N. Nikoloulis, H. Tziourganou, A. Tsaroucha, A. Papadopoulou, A. Douras; HUNGARY Budapest: L. Polgar, B. Merkely, A. Kosztin, N. Nyolczas, A. Csaba Nagy; Pecs (Baranya): R. Halmosi; ISRAEL Hadera: J. Elber, I. Alony, A. Shotan, A. Vazan Fuhrmann; Haifa: O. Amir; ITALY Atri: S. Romano, S. Marcon, M. Penco, M. Di Mauro, E. Lemme; Brescia: V. Carubelli, R. Rovetta, M. Metra, M. Bulgari, F. Quinzani, C. Lombardi; Cotignola: S. Bosi, G. Schiavina, A. Squeri, A. Barbieri; Cremona: G. Di Tano, S. Pirelli; Ferrara: R. Ferrari, A. Fucili; Foggia: T. Passero, S. Musio, M. Di Biase, M. Correale, G. Salvemini; Lumezzane: S. Brognoli, E. Zanelli, A. Giordano; Milano: P. Agostoni, G. Italiano, E. Salvioni; Modena: S. Copelli, M.G. Modena, L. Reggianini, C. Valenti, A. Olaru; Monserrato: S. Bandino, M. Deidda, G. Mercuro, C. Cadeddu Dessalvi; Novara: P.N. Marino, M.V. Di Ruocco, C. Sartori, C. Piccinino; Palermo: G. Parrinello, G. Licata, D. Torres, S. Giambanco, S. Busalacchi, S. Arrotti, S. Novo, R.M. Inciardi, P. Pieri, P.R. Chirco, M. Ausilia Galifi, G. Teresi, D. Buccheri, A. Minacapelli; Passirana di Rho (Milano): M. Veniani, A. Frisinghelli; Pavia: S.G. Priori, S. Cattaneo, C. Opasich, A. Gualco; Roma: M. Pagliaro, M. Mancone, F. Fedele, A. Cinque, M. Vellini, I. Scarfo, F. Romeo, F. Ferraiuolo, D. Sergi; San Bonifacio (Verona): M. Anselmi; Sassuolo: F. Melandri, E. Leci, E. Iori; Torino: V. Bovolo, S. Pidello, S. Frea, S. Bergerone, M. Botta, F.G. Canavosio, F. Gaita; Trieste: M. Merlo, M. Cinquetti, G. Sinagra, F. Ramani, E. Fabris, D. Stolfo; Udine: J. Artico, D. Miani, C. Fresco, C. Daneluzzi, A. Proclemer; Verona: M. Cicoira, L. Zanolla, G. Marchese, F. Torelli, C. Vassanelli; LATVIA Jelgava: N. Voronina; Riga: A. Erglis; LITHUANIA Kaunas: V. Tamakauskas, V. Smalinskas, R. Karaliute, I. Petraskiene, E. Kazakauskaite, E. Rumbinaite, A. Kavoliuniene; Marijampole: V. Vysniauskas, R. Brazyte-Ramanauskiene, D. Petraskiene; POLAND Biala: S. Stankala, P. Switala, Z. Juszczyk; Bydgoszcz: W. Sinkiewicz, W. Gilewski, J. Pietrzak; Chelmza: T. Orzel, P. Kasztelowicz; Czestochowa: P. Kardaszewicz, M. Lazorko-Piega, J. Gabryel; Gdansk: K. Mosakowska, 
J. Bellwon, A. Rynkiewicz, G. Raczak, E. Lewicka, A. Dabrowska-Kugacka; Kielce: R. Bartkowiak, B. Sosnowska-Pasiarska, B. Wozakowska-Kaplon; Kluczbork: A. Krzeminski; Krakow: M. Zabojszcz, E. Mirek-Bryniarska, A. Grzegorzko, K. Bury, J. Nessler, J. Zalewski, A. Furman; Lodz: M. Broncel, A. Poliwczak, A. Bala, P. Zycinski, M. Rudzinska, L. Jankowski, J.D. Kasprzak, L. Michalak, K. Wojtczak Soska, J. Drozdz, I. Huziuk, A. Retwinski; Lublin: P. Flis, J. Weglarz, A. Bodys; Poznan: S. Grajek, M. Kaluzna-Oleksy, E. Straburzynska-Migaj, R. Dankowski, K. Szymanowska, J. Grabia, A. Szyszka, A. Nowicka; Pruszkow: M. Samcik, L. Wolniewicz, K. Baczynska, K. Komorowska, I. Poprawa, E. Komorowska, D. Sajnaga, A. Zolbach, A. Dudzik-Plocica, A-F. Abdulkarim, A. Lauko-Rachocka; Przeworsk: L. Kaminski, A. Kostka, A. Cichy; Sieradz: P. Ruszkowski, M. Splawski; Starachowice: G. Fitas, A. Szymczyk, A. Serwicka, A. Fiega; Strzegom: D. Zysko; Szczecin: W. Krysiak, S. Szabowski, E. Skorek; Warszawa: P. Pruszczyk, P. Bienias, M. Ciurzynski, M. Welnicki, A. Mamcarz, A. Folga, T. Zielinski, T. Rywik, P. Leszek, M. Sobieszczanska-Malek, M. Piotrowska, K. Kozar-Kaminska, K. Komuda, J. Wisniewska, A. Tarnowska, P. Balsam, M. Marchel, G. Opolski, A. Kaplon-Cieslicka, R.J. Gil, O. Mozenska, K. Byczkowska, K. Gil, A. Pawlak, A. Michalek, P. Krzesinski, K. Piotrowicz, B. Uzieblo-Zyczkowska, A. Stanczyk, A. Skrobowski; Wroclaw: P. Ponikowski, E. Jankowska; Zabrze: P. Rozentryt, L. Polonski, E. Gadula-Gacek, E. Nowalany-Kozielska, A. Kuczaj, Z. Kalarus, M. Szulik, K. Przybylska, J. Klys; Zamosc: G. Prokop-Lewicka, A. Kleinrok; PORTUGAL Carnaxide: C. Tavares Aguiar, A. Ventosa; Faro: S. Pereira, R. Faria, J. Chin, I. De Jesus; Guilhufe-Penafiel: R. Santos, P. Silva, N. Moreno, C. Queirós, C. Lourenço, A. Pereira, A. Castro, A. Andrade; Lisboa: T. Oliveira Guimaraes, S. Martins, R. Placido, G. Lima, D. Brito, A.R. Francisco, R. Cardiga, M. Proenca, I. Araujo, F. Marques, C. Fonseca; Porto: B. Moura, S. Leite, M. Campelo, J. Silva-Cardoso, J. Rodrigues, I. Rangel, E. Martins, A. Sofia Correia; Santarem: M. Peres, L. Marta, G. Ferreira da Silva, D. Severino, D. Durao; Vila Real: S. Leao, P. Magalhaes, I. Moreira, A. Filipa Cordeiro, C. Ferreira, C. Araujo, A. Ferreira, A. Baptista; ROMANIA Brasov: M. Radoi; Bucharest: G. Bicescu, D. Vinereanu, C-J. Sinescu, C. Macarie, R. Popescu, I. Daha, G-A. Dan, C. Stanescu, A. Dan; Constanta: E. Craiu; Galati: E. Nechita; Iasi: V. Aursulesei; Timisoara: R. Christodorescu; SERBIA Belgrade: P. Otasevic, P.M. Seferovic, D. Simeunovic, A.D. Ristic, V. Celic, M. Pavlovic-Kleut, J. Suzic Lazic, B. Stojcevski, B. Pencic, A. Stevanovic, A. Andric; Kragujevac: V. Iric-Cupic, M. Jovic, G. Davidovic, S. Milanov; Nis: V. Mitic, V. Atanaskovic, S. Antic, M. Pavlovic, D. Stanojevic; Niska Banja: V. Stoickov, S. Ilic, M. Deljanin Ilic, D. Petrovic; Sremska Kamenica (Vojvodina): S. Stojsic, S. Kecojevic, S. Dodic, N. Cemerlic Adic, M. Cankovic, J. Stojiljkovic, B. Mihajlovic, A. Radin; Zemun, Belgrade: S. Radovanovic, M. Krotin; SLOVAKIA Banovce nad Bebravou: A. Klabnik; Bratislava: E. Goncalvesova, M. Pernicky, J. Murin; Martin: F. Kovar; Presov: J. Kmec, H. Semjanova; SLOVENIA Brezice: M. Strasek, M. Savnik Iskra; Izola: T. Ravnikar, N. Cernic Suligoj, J. Komel; Ljubljana: Z. Fras, B. Jug; Maribor: T. Glavic, R. Losic, M. Bombek, I. Krajnc, B. Krunic; Murska Sobota: S. Horvat, D. Kovac, D. Rajtman; Ptuj: V. Cencic, M. Letonja; Sempeter pri Novi Gorici: R. Winkler, M. Valentincic, C. Melihen-Bartolic, A. Bartolic; Slovenj Gradec: M. Pusnik Vrckovnik, M. Kladnik, C. Slemenik Pusnik, A. Marolt; Trbovlje: J. Klen, B. Drnovsek, B. Leskovar; SPAIN Albacete: M.J. Fernandez Anguita, J.C. Gallego Page, F.M. Salmeron Martinez; Barakaldo (Vizcaya): J. Andres; Barcelona: A.B. Genis, S. Mirabet, A. Mendez, L. Garcia-Cosio, E. Roig, V. Leon, J. Gonzalez-Costello, G. Muntane, A. Garay; Granada: V. Alcade-Martinez, S. Lopez Fernandez, R. Rivera-Lopez, M. Puga-Martinez, M. FernandezAlvarez, J.L. Serrano-Martinez; La Coruna: M. Crespo-Leiro, Z. Grille-Cancela, R. Marzoa-Rivas, P. Blanco-Canosa, M.J. Paniagua-Martin, E. Barge-Caballero; La Laguna - Santa Cruz de Tenerife (Canary Islands): I. Laynez Cerdena, I. Famara Hernandez Baldomero, A. Lara Padron; Madrid: S. Ofelia Rosillo, R. Dalmau Gonzalez-Gallarza, O. Salvador Montanes, A.M. Iniesta Manjavacas, A. Castro Conde, A. Araujo, T. Soria, P. Garcia-Pavia, M. Gomez-Bueno, M. Cobo-Marcos, L. AlonsoPulpon, J. Segovia Cubero, I. Sayago, A. Gonzalez-Segovia, A. Briceno, P. Escribano Subias, M. Vicente Hernandez, M.J. Ruiz Cano, M.A. Gomez Sanchez, J.F. Delgado Jimenez, E. Barrios Garrido-Lestache; Malaga: J.M. Garcia Pinilla; Manacor (Mallorca): B. Garcia de la Villa, A. Sahuquillo; Marbella (Malaga): R. Bravo Marques, F. Torres Calvo; Murcia: M.T. Perez-Martinez, M.R. Gracia-Rodenas, I. P. Garrido-Bravo, F. Pastor-Perez, D.A. Pascual-Figal; Oviedo: B. Diaz Molina; Sabadell (Barcelona): J. Orus, F. Epelde Gonzalo; San Juan de Alicante: V. Bertomeu, R. Valero, R. Martinez-Abellan, J. Quiles, J.A. Rodrigez-Ortega, I. Mateo, A. ElAmrani; Sevilla: C. Fernandez-Vivancos; Tortosa: D. Bierge Valero; Valencia: L. Almenar-Bonet, I.J. Sanchez-Lazaro, E. Marques-Sule, L. Facila-Rubio, J. Perez-Silvestre, P. Garcia-Gonzalez, F. Ridocci-Soriano, D. Garcia-Escriva, A. Pellicer-Cabo; 
Valladolid: L. de la Fuente Galan, J. Lopez Diaz, A. Recio Platero; Vigo: J.C. Arias; Zaragoza: T. Blasco-Peiro, M. Sanz Julve, E. Sanchez-Insa, C. Aured-Guallar, A. Portoles-Ocampo; SWEDEN Stockholm: M. Melin, E. Hägglund; Lindesberg: A. Stenberg, I-M. Lindahl; Varberg: B. Asserlund, L. Olsson; Linköping: U. Dahlström, M. Afzelius; Jönköping: P. Karlström, L. Tengvall; Kristianstad: PA.Wiklund, B. Olsson; TURKEY Ankara: S. Kalayci, A. Temizhan; Eskisehir: Y. Cavusoglu; Kilis: E. Gencer; Sivas: M.B. Yilmaz, H. Gunes.

\section{References}

1. Kenchaiah S, Evans JC, Levy D, Wilson PW, Benjamin EJ, Larson MG, Kannel WB, Vasan RS. Obesity and the risk of heart failure. N Engl J Med 2002;347:305-313.

2. Horwich T, Fonarow G, Hamilton MA, MacLellan WR, Woo MA, Tillisch JH. The relationship between obesity and mortality in patients with heart failure. J Am Coll Cardiol 2001;38:789-795.

3. Lavie CJ, Osman AF, Milani RV, Mehra MR. Body composition and prognosis in chronic systolic heart failure: the obesity paradox. Am J Cardiol 2003;91:891-894.

4. Bozkurt B, Deswal A. Obesity as a prognostic factor in chronic symptomatic heart failure. Am Heart J 2005;150:1233-1239.

5. Kenchaiah S, Pocock SJ, Wang D, Finn PV, Zornoff LA, Skali H, Pfeffer MA, Yusuf S, Swedberg K, Michelson EL, Granger CB, McMurray JJ, Solomon SD; CHARM investigators. Body mass index and prognosis in patients with chronic heart failure: insights from the Candesartan in Heart failure: Assessment of Reduction in Mortality and morbidity (CHARM) program. Circulation 2007;116:627636.

6. Oreopoulos A, Padwal R, Kalantar-Zadeh K, Fonarow GC, Norris CM, McAlister FA. Body mass index and mortality in heart failure: a meta-analysis. Am Heart J 2008;156:13-22.

7. Fonarow GC, Srikanthan P, Costanzo MR, Cintron GB, Lopatin M; ADHERE Scientific Advisory Committee and Investigators. An obesity paradox in acute heart failure: analysis of body mass index and in-hospital mortality for 108,927 patients in the Acute Decompensated Heart Failure National Registry. Am Heart J 2007;153:74-81.

8. Sharma A, Lavie CJ, Borer JS, Vallakati A, Goel S, Lopez-Jimenez F, Arbab-Zadeh A, Mukherjee D, Lazar JM. Meta-analysis of the relation of body mass index to all-cause and cardiovascular mortality and hospitalization in patients with chronic heart failure. Am J Cardiol 2015;115:1428-1434.

9. Zafrir B, Adir Y, Shehadeh W, Shteinberg M, Salman N, Amir O. The association between obesity, mortality and filling pressures in pulmonary hypertension patients; the 'obesity paradox'. Respir Med 2013;107:139-146.

10. Zafrir B, Salman N, Amir O. Joint impact of body mass index and physical capacity on mortality in patients with systolic heart failure. Am J Cardiol 2014;113:1217-1221.

11. Rossignol P, Masson S, Barlera S, Girerd N, Castelnovo A, Zannad F, Clemenza F, Tognoni G, Anand IS, Cohn JN, Anker SD, Tavazzi L, Latini R; GISSI-HF and Val-HeFT Investigators. Loss in body weight is an independent prognostic factor for mortality in chronic heart failure: insights from the GISSI-HF and Val-HeFT trials. Eur J Heart Fail 2015;17:424-433.

12. Guglin M, Baxi K, Schabath M. Anatomy of the obesity paradox in heart failure. Heart Fail Rev 2014;19:621-635.

13. Gupta PP, Fonarow GC, Horwich TB. Obesity and the obesity paradox in heart failure. Can J Cardiol 2015;31:195-202.

14. Frankenstein L, Zugck C, Nelles M, Schellberg D, Katus HA, Remppis BA. The obesity paradox in stable chronic heart failure does not persist after matching for indicators of disease severity and confounders. Eur J Heart Fail 2009;11:1189-1194

15. Zafrir B, Goren Y, Salman N, Amir O. Comparison of body mass index and body surface area as outcome predictors in patients with systolic heart failure. Cardiol J 2015;22:375-381.

16. Lavie CJ, Ventura HO. Analyzing the weight of evidence on the obesity paradox and heart failure. Is there a limit to the madness? Congest Heart Fail 2013;19:158-159.

17. Chase PJ, Davis PG, Bensimhon DR. The obesity paradox in chronic heart failure: what does it mean? Curr Heart Fail Rep 2014;11:111-117.

18. Wu AH, Pitt B, Anker SD, Vincent J, Mujib M, Ahmed A. Association of obesity and survival in systolic heart failure after acute myocardial infarction: potential confounding by age. Eur J Heart Fail 2010;12:566-573.

19. Clark AL, Foranow GC, Horwich TB. Waist circumference, body mass index, and survival in systolic heart failure: the obesity paradox. J Card Fail 2011;17:374-380. 
20. Futter JE, Cleland JG, Clark AL. Body mass indices and outcome in patients with chronic heart failure. Eur J Heart Fail 2011;13:207-213.

21. Ristow B, Ali S, Na B, Turakhia MP, Whooley MA, Schiller NB. Predicting heart failure hospitalization and mortality by quantitative echocardiography: is body surface area the indexing method of choice? The Heart and Soul Study. J Am Soc Echocardiogr 2010;23:406-413.

22. Maggioni AP, Anker SD, Dahlström U, Filippatos G, Ponikowski P, Zannad F, Amir O, Chioncel O, Leiro MC, Drozdz J, Erglis A, Fazlibegovic E, Fonseca C,Fruhwald F, Gatzov P, Goncalvesova E, Hassanein M, Hradec J, Kavoliuniene A, Lainscak M, Logeart D, Merkely B, Metra M, Persson H, Seferovic P, Temizhan A, Tousoulis D, Tavazzi L; Heart Failure Association of the ESC. Are hospitalized or ambulatory patients with heart failure treated in accordance with European Society of Cardiology guidelines? Evidence from 12440 patients of the ESC Heart Failure Long-Term Registry. Eur J Heart Fail 2013;15:1173-1184.

23. Mosteller RD. Simplified calculation of body surface area. N Engl J Med 1987;317:1098

24. Verbraecken J, Van de Heyning P, De Backer W, Van Gaal L. Body surface area in normal weight, overweight, and obese adults. A comparison study. Metabolism 2006;55:515-524.

25. Shah R, Gayat E, Januzzi JL Jr, Sato N, Cohen-Solal A, diSomma S, Fairman E, Harjola VP, Ishihara S, Lassus J, Maggioni A, Metra M, Mueller C, Mueller T, Parenica J, Pascual-Figal D, Peacock WF, Spinar J, van Kimmenade R, Mebazaa A; GREAT (Global Research on Acute Conditions Team) Network. Body mass index and mortality in acutely decompensated heart failure across the world: a global obesity paradox. J Am Coll Cardiol 2014;63:778-785.

26. Lavie CJ, Alpert MA, Arena R, Mehra MR, Milani RV, Ventura HO. Impact of obesity and the obesity paradox on prevalence and prognosis in heart failure. JACC Heart Fail 2013;1:93-102.

27. Farré N, Aranyó J, Enjuanes C, Verdú-Rotellar JM, Ruiz S, Gonzalez-Robledo G, Meroño O, de Ramon M, Moliner P, Bruguera J, Comin-Colet J. Differences in neurohormonal activity partially explain the obesity paradox in patients with heart failure: the role of sympathetic activation. Int $J$ Cardiol 2015;181:120-126.

28. Gibson S, Numa A. The importance of metabolic rate and the folly of body surface area calculations. Anaesthesia 2003;58:50-55.

29. DuBois D, DuBois EF. A formula to estimate the approximate surface area if height and weight be known. Nutrition 1989;5:303-311.

30. Habib RH, Zacharias A, Schwann TA, Riordan CJ, Durham SJ, Shah A. Effects of obesity and small body size on operative and long-term outcomes of coronary artery bypass surgery: a propensitymatched analysis. Ann Thorac Surg 2005;79:1976-1986.

31. Komoda T, Drews T, Hetzer R, Lehmkuhl HB. Adult candidates for heart transplantation with larger body surface area have better prognosis on waiting list after progression to critically ill status. Eur $J$ Cardiothorac Surg 2011;39:317-2320. 